Adnan Kadrić

Orijentalni institut

Univerziteta u Sarajevu, BiH

http://dx.doi.org/10.18778/8088-249-2.08

\title{
LIMINALNO-HETEROGENA POETIKA STARIJE BOŠNJAČKE KNJIŽEVNOSTI U KONTEKSTU ZAPADNOBALKANSKE KULTUROLOŠKE POLIFONIJE
}

Pojam liminalnog u književnohistorijskim i kulturološkim studijama sve je češći i u analizi djela u starijoj literarnoj tradiciji/tradicijama na Zapadnom Balkanu. Kada se spomenuti pojam pokušava analizirati na primjeru starije bošnjačke književnosti, a u kontekstu heterogene poetike brojnih djela nastalih ina orijentalnim jezicima, ali i na maternjem, bosanskom jeziku, uočava se posebna vrsta ciklične liminalnosti svojstvene za književnosti nastale u višestoljetnom kontaktu različitih i jezičkih i kulturološko-civilizacijskih svjetova, pri čemu se fenomen kulturološke polifonije preslikava iz sfere identitarnog u sferu poetskog literarnog teksta. Pritom se raznolikost tradicija pretvara više u višeslojni složeni mozaik s brojnim sličnostima i razlikama, a manje u pojednostavljenu crnobijelu nacionalno-romantičarsku viziju literarno-kulturološkog jednoglasja, kako $\mathrm{u}$ definiranju pojma nacionalnog tako i u (re)afirmiranju pojma nadnacionalnog u književnosti(ma), prilikom svake kulturološke analize tekstova nastalih u kulturološko-polifonijskom ambijentu literarnog stvaralaštva na Balkanu u osmanskom periodu. U bošnjačkoj književnosti 20. stoljeća samo donekle je prisutan utjecaj spomenute ideje u književnom stvaralaštvu pojedinih autora uglavnom kroz mimetički šablonizirane forme preuzete ili iz klasične ili moderne poetike književnih djela iz različitih jezičko-kulturoloških literarnih tradicija koja se imitiraju ili iz razloga kulturološko-povijesne naravi, pokušaja reafirmiranja ranije tradicije ili iz čisto „praktičnih“ motiva određenih bosanskih autora slavenskog porijekla koji su pisali na nekom od orijentalnih jezika.

\section{1.}

U članku „Kulturalno-poetički sinkretizmi i liminalno-hibridni oblici kao kulturalno-memorijski i interliterarni fenomen novije bošnjačke/ bosanskohercegovačke književnosti: na primjeru ranog pjesničkog djela Safvetbega Bašagića“" [Kodrić 2013: 187-215], Kodrić skreće pažnju na to da noviju 
bošnjačku književnost jednim dijelom karakteriziraju kulturalno-poetički sinkretizmi i liminalno-hibridnioblici, gradeći osoben poetičko-identitarni svijet novije bošnjačke i bosanskohercegovačke literarne tradicije. Ovim radom želimo skrenuti pažnju na važnu činjenicu da se navedena osobenost bošnjačke i bosanskohercegovačke literarnetradicijemože uočitiina brojnim primjerimai djelimakoja seu antologijama i književnokritičkim pregledima bošnjačke književnosti uvrštavaju u djela starije bošnjačke književnosti. Na spomenuti fenomen ukazuju također radovi Midhata Begića [Begić 1987: 130-142], Muhsina Rizvića [Rizvić 1994: 7-42], Enesa Durakovića [Duraković 1998: 67-72], kao i radovi drugih teoretičara i historičara bošnjačke i bosanskohercegovačke literarne tradicije [Džanko 2001: 1-10]. Rizvić afirmira hipotezu o „ponornom“ karakteru poetike bošnjačke književnosti [Rizvić 1994: 34-35; Kodrić 2013: 190], koja se u određenom periodu gubi, ponire da bi se kasnije ponovno pojavila u sličnim formama.

U kontekstu zapadnobalkanske kulturološke polifonije vrlo je teško ustvrditi kako je starija bošnjačka književnost, iz konfesionalno-kulturološkog i/ili lingvističkog motrišta, manje ili više „interkulturalna“ nego što je to, naprimjer, starija hrvatska književnost, ili, pak, bilo koja književnost koja u svoje književnohistorijsko naslijeđe inkorporira literarna djela na latinskom jeziku. S druge strane, s obzirom na široko razumijevanje pojma „liminalnosti“ u antropologiji, pri čemu se faza prije liminalne faze označava kao početak identitarne promjene pojedinca ili kolektiva, dok se liminalna faza označava kao faza nestajanja jednog i neusvajanja drugog kulturalnog identiteta u pravom smislu riječi, moguće je doći do zaključka da sve poetike u različitim svjetskim literarnim tradicijama, postmodernistički promatrano, dolaze u fazu građenja cikličnih identitarno-kulturoloških krugova u različitim fazama razvitka. Ukratko, sasvim je moguće znanstveno i kulturološko-antropološki afirmirati i pojam ciklično-liminalne kulturalne poetike bošnjačke književnosti uopće. Radi se prije svega o različitim kulturalnim i literarnim tekstualnim poetikama koje se stapaju u jedinstveni identitarni spoj koji sadrži naizgled podjednako međusobno različite kulturološko-civilizacijske odrednice ${ }^{1}$. Budući da su one u svojim nijansama

1 Poetske forme u starijoj bošnjačkoj literarnoj tradiciji slijede unutarnju logiku razvoja žanra, periode stagnacije estetskih kriterija kod pojedinaca ili u zajednici, pa čak i silaznu putanju u razvoju ,jezičke poetike teksta“. Osim toga, poetski jezik, strogo stilistički promatrajući, podrazumijeva svojevrsni diskontinuitet uobičajene, svakodnevne upotrebe jezika, dok se polisemantični diskurs, koji teži ka promjeni/ transgresiji uobičajenog svakodnevnog iskustva, po svojoj naravi kreće ka liminalnim razdjelincama osjetilnog i umnog u poetskom opusu i pojedinca i kolektiva. Liminalnost je temeljna odrednica razvoja, pretvorbe jednog oblika ili epohe, kada slijedi prelazak $\mathrm{u}$ narednu fazu uz zadržavanje elemenata prethodne epohe. U pogledu identiteta, tekst se osjeća dijelom literarnog identiteta više zbog sadržaja, nego zbog forme iskazivanja. 
sastavni dio cjelovitog povijesnog kulturalnog identiteta, pojedinačno dolaze do izražaja u kriznim povijesnim razdobljima. Liminalnost evropske kulturalne poetike u književnosti renesanse i kasnijih razdoblja najčešće se prepoznaje kroz određene stilske periode a ciklična liminalnost podrazumijeva okretanje antičkim grčkim kulturalnim uzorima u vrijeme dok se na duhovnom planu u Evropi vodi bitka za prevlast reformacijskih ili protureformacijskih religijskih pokreta. Balkan je vrlo zanimljiv za takve vrste proučavanja, a osobito u pogledu kulturološke resemantizacije postojeće, zatečene literarne tradicije. Naime, kulturološka poetička resemantizacija u značenju „prelaženja kulturološkog praga“ u pisanoj i usmenoj tradiciji, odnosno djelomična identitarna pretvorba fenomeni su rašireni u svim civilizacijama svijeta i u brojnim literarnim tradicijama u svijetu.

Vremenski ciklusi u razvoju jezika i književnosti uvijek podrazumijevaju kraće ili duže periode (dis)kontinuiteta. Diskontionuitet je tek period u dijelovima pravolinijskog kontinuiteta. Resemantizacija i supstitucija dijela kulturalnih i duhovnih vrijednosti određenog kolektiva ne brišu njegov povijesni kontinuitet. Naime, povijesni literarni identitet određene skupine odražava se istovremeno i u jeziku, i u literarnim poetskim obrascima, ali i u kulturi i samom „čovjeku“, odnosno pojedincu ma kojoj etničkoj skupini on pripadao. Navedeno posebno dolazi do izražaja na prostoru Balkana, prostoru stalnog dodira i koketiranja „doseljene“ slavenske tradicije i sa Zapadom i sa Istokom. Osim globalnog „koketiranja“ kulturalnih tradicija, na prostoru zapadnog Balkana stvari u historiji književnosti dodatno se usložnjavaju i relativno kasno probuđenim „nacionalnoromantičarskim" koketiranjima zapadnobalkanskog Istoka i Zapada, koji se također žele diferencirati na konfesionalno-kulturalnom principu i pojačati, na toj osnovi, čisto etnički princip u „formiranju“ kako identiteta tako i književnosti i jezika, zaokruživši taj proces primarnom etnizacijom povijesti i svijesti, gradeći novu, ideološki koncipiranu povijest književnosti.

\section{2.}

Starija bošnjačka literarna tradicija nastaje na razmeđu Istoka i Zapada, na čvorištu resemantiziranih kulturalnih svjetova, između Rima i Bizanta, a kasnije Orijenta, odnosno Osmanlija i slavenskih ideja pretočenih u složeni mozaik bosanske duhovnosti. Pitanje „liminalnosti identiteta“ u kasnom srednjovjekovlju i ranom novovjekovlju nije bilo sudbinski razlikovno. U spomenutom periodu brakovi između pripadnika različitih naroda jačali su interese određenih dinastija, a vjerska i kulturološka identifikacija postepeno se razvijala, uglavnom kroz sistem obrazovanja. Srednjovjekovna bosanska književnost bila je bitno obilježena djelima koja su važila za univerzalna djela, odnosno žanrovske forme u široj južnoslavenskoj interliterarnoj zajednici. Sa dolaskom Osmanlija/Turaka na prostor Balkana dolazi do usložnjavanja procesa resemantizacije određene 
literarne i kulturalne tradicije. Pored susreta latinskog, grčkog i južnoslavenskih jezika na području Balkana dolazi i do širenja literature na orijentalnim jezicima. O složenom hibridnom karakteru nove kulturalne i literarne zajednice na prostoru Balkana u „ranom periodu“ dosta govore sačuvane usmene predaje koje su sporadično bilježene u različitim formama kako na slavenskim tako i na osmanskom jeziku. Opis Boja na Kosovu sličan je i u usmenoj epici na slavenskim i na osmanskom turskom jeziku, opis osvajanja Bosne sličan je i na slavenskim i na osmanskom jeziku. (Opis epskih junaka: Alija Đerzelez, Jakubpaša Bošnjak, Ahmed-paša Hercegović i sl.). S druge strane, literarni žanr „aleksandrida“ prisutan je i na slavenskim jezicima, u bizantijskoj književnosti, ali i na osmanskom jeziku. Razlika između bosanske Aleksandride na bosanskom jeziku (Berlinska Aleksandrida) i bosanske Aleksandride, na primjer, na arapskom jeziku (Aleksandrida Ali Dedea Mostarca) u 16. stoljeću pokazuje više razliku u putevima predaje nego izvorne teme i motiva. Predaje su, dakako, različito kulturološki resemantizirane. Naime, primjer pripovijesti o Aleksandru Velikom u starijoj bošnjačkoj književnosti u svoj svojoj strukturalnoj kompozitnosti i poetičkoj heterogenosti na najbolji način oslikava takvu vrstu nadopunjavanja u interliterarnom jedinstvu različito kulturološki „,resemantiziranih“ pripovijesti o spomenutom antičkom junaku koji je i sam nadrastao granice pojedinačnog identitarnoga određenja i postao jednim od univerzalnih svjetskih simbola mudrosti i junaštva.

\section{3.}

Na sposobnosti da se postane univerzalnim kroz preplitanje raznolikosti na razini pojedinačnih narativnih identiteta tekstova temelji se snaga i univerzalna vrijednost određene literarne poruke, kako Paol Ricouer naglašava, „usprkos i pomoću njihovog kontrasta" [Riker 2004: 170]. Starija bosanskohercegovačka i bošnjačka literarna tradicija baštini takve literarne varijante u kontaktu, koje su naprosto odraz velikih interliterarnih zajednica u kontaktu realiziran kroz djelo lokalnih autora. $\mathrm{O}$ takvim interliterarnim kontaktima na Balkanu treba voditi računa u književnoznanstvenim komparatističkim studijama u bosniakističkim i bosnističkim istraživanjima u užem i širem smislu. Svjetska književnost je puna takvih primjera, gdje se kroz određeni "model razumijevanja“ jedna priča „uglavljuje“ u neku drugu priču. Neki autori su u mladosti promijenili religiju tako da su njihova djela ovisila o novoj „kulturalnoj resemantizaciji“ i literarnoj tradiciji. Navest ćemo primjer potomaka srednjovjekovne bosanske plemićke porodice Vukčića Kosača, odnosno primjer pjesnika Stjepana/Ahmed-paše Hercegovića i Ali-bega Širija Hercegovića, s jedne strane, te primjer Hasana Alemdara koji je primio katoličanstvo kao dijete i pisao svoje djela pod imenom Fra Lovro Šitović (1682-1729), pišući na maternjem i na latinskom jeziku 
(Pisna od pakla, 1727. i druge tekstove), kao i gramatiku Grammatica latinoillyrica (1713). Franjevački pisac fra Matija Divković izjašnjavao se u svojim djelima kao Bošnjak, a za jezik navodio da je bosanski. No, njegovo naglašeno bošnjaštvo bilo je više iz ljubavi prema Bosni nego iz želje da se razlikuje od neke druge kulturalne tradicije na spomenutom prostoru u prvoj polovini 17. stoljeća. Napisao je djela Nauk krstjanski za narod slovinski, te je preveo popularno djelo Sto čudesa aliti znamenja blažene i slavne Bogorodice. U njegovo vrijeme živio je i Muhamed Hevai Uskufi koji je napisao u stihovima 1643. godine Bosansko-turski rječnik Makbul-i Arif, ali je također napisao i nekoliko poznatih alhamijado pjesama na bosanskom jeziku, arapskim pismom. Liminalnost u pogledu kulturalne poetike spomenutih dvojice autora očigledna je: na isti ili sličan način koliko se jedan od autora udaljava od poetike tekstova na latinskom jeziku, pišući svoje tekstove na bosanskom jeziku, toliko se drugi autor udaljava od poetike tekstova na osmanskom jeziku i piše također pjesme na maternjem, bosanskome jeziku. Čak im je i stil sličan, s nužnom razlikom u registarskoj upotrebi jezika. Također je zanimljiv primjer bosanskog franjevca fra Grge Martića koji je, prema zapisima hroničara, napisao tekst za himnu osmanske vojske u Bosni. Navedeni primjeri navode se kao slikoviti za određivanje paradigme kulturalne liminalnosti koja zadržava istu identitarnu narodnosnu povezanost obojice autora za Bosnu i maternji jezik, bez obzira na religijsku pripadnost koja je više nego jasna svakom književnom kritičaru. Ahmed Dževdet-paša piše u svojim izvještajima (tezākir) kako je glavni franjevački fratar fra Grga Martić, koji se nalazio u Sarajevu, napisao himnu za reformiranu osmansku vojsku u formi pjesme za podsticanje u boj „manzūme-i teşvìqiye”, koju pisac daje na osmanskom jeziku uz prevod svakog stiha: Tekst prve strofe glasi:

\author{
Sunce se pojavi, zrake bljesnuše \\ Bosni se Sultan nasmiješi \\ Uzvišeni ferman odaslaše \\ Mlade momke za vojsku traži \\ Hajde, hajde, pod bajrak vi dođite! [Cevdet Paşa 1991: 77]
}

Osmanski putopisac i carski kontrolor Dževdet-paša stalno ukazuje na svakodnevni život u Bosni, napominjući da je juzbaša Fuad-aga sastavio muziku koja je prikladna za Bošnjake kako bi se po toj melodiji pjevala pjesma fra Grge Martića. Također napominje da je Fuad-aga bio vrlo spretan i da je se bosanskim kafanama uz saz pjevala narodna junačka pjesma koja je posebno veselila Bošnjake, a govorila je o pobjedi Hekimoglu Ali-paše nad Nijemcima. Od poeme fra Grge Martića Fuad-aga je na melodijsku intonaciju spomenute epske pjesme sastavio lijep marš i melodiju koja je pratila vojsku na postrojavanju. Iz dopisa osmanskog putopisca jasno je da je u Bosni i u osmanskom periodu dominantna komunikacija bila na maternjem, bosanskom jeziku, da su se 
pjevali epovi o velikim bitkama, da je prvi bosanski odred u to vrijeme slušao koračnicu na bosanskom jeziku, a autor te pjesme bio je bosanski franjevac fra Grga Martić. Navedeni primjer dosta govori o aktivnoj koegzistenciji i multikulturalnosti Bosne u različitim vremenima, što se slikovito uočava i na polju umjetnosti kada fra Grga Martić i Fuad-aga zajednički sastavljaju pjesmu koračnicu za bosansku vojsku².

\section{4.}

Zapadnobalkanska kulturalna polifonija povijesno je uvjetovana istim geografskim prostorom i sudbinom ljudi na tom prostoru zajedničkog življenja. Komparacija tekstova određenog geografskog prostora koji govore o gotovo istim događajima i fenomenima nužna je za bolje sagledavanje recepcije/doživljaja događaja koji se opisuju. Malo gdje u Evropi srećemo, kao što je to slučaj u Bosni, gotovo sve imagološke „varijante“ u književnom opisu istih događaja, sa stajališta najmanje tri, četiri, pa i više ideoloških perspektiva. Ne treba zaboraviti da bošnjačka književna tradicija na orijentalnim jezicima nije ništa manje interesantna za kulturalnopoetička istraživanja od brojnih drugih tekstova iz različitih konfesionalno kulturoloških književnih zajednica iz susjedstva. Dakako, za studije teorijske naravi bošnjačka književnost je, zbog specifičnih uvjeta razvoja, izuzetno pogodno tlo za razvoj brojnih načina proučavanja bosanskohercegovačke književne komparativistike, koja je nužna da ukaže na opći kontekst i stanje interliterarne južnoslavenske zajednice koja je opstojala u različitim carstvima i „dominacijama“ različitih „literarnih“ jezika, premda pod utjecajima različitih obrazovnih sistema koji su se nametali i nadmetali na istim geografskim prostorima, (u)noseći i bogatstvo i mjesta kulturološkocivilizacijskih razlikovanja koja su u periodima mira predstavljala mjesto „sretnog susreta" različitih kulturoloških i književnih modela, a u periodima sukoba mjesto razlikovnosti i imagološkog proturječja. Zanimljiv je fenomen odraza negiranja određenih razvojnih faza starije bošnjačke literarne tradicije u djelima modernih pisaca i pjesnika. Vrlo čest je motiv povezivanja moderne bošnjačke književnosti sa značajnim historijskim figurama važnim za slavensku historiografiju, dok fenomen povezivanja moderne bošnjačke književnosti sa pismenošću srednjovjekovne Bosne naprosto potvrđuje vrlo izraženu potrebu i opću osobinu književne kritike - težnju ka reafirmaciji tzv. povijesnog ciklično-

${ }^{2} \mathrm{U}$ austrougarskom periodu dolazi do većeg približavanja literarne produkcije bosanskih muslimana, katolika i pravoslavaca unutar šire južnoslavenske interliterarne zajednice. $\mathrm{O}$ tome pišu brojni književni kritičari. $\mathrm{U}$ posljednje vrijeme po pristupu se izdvaja knjiga Književnost sjećanja: Kulturalno pamćenje i reprezentacija prošlosti u novijoj bošnjačkoj književnosti [Kodrić 2012]. 
liminalnog literarnog identiteta pisane tradicije Bosne od najstarijih vremena do danas. To je, čini se, opća težnja u svim svjetskim književnostima i književnoj kritici općenito.

\section{Umjesto zaključka}

Zapadnobalkanska kulturalna polifonija fenomen je koji svjedoči o bogatstvu kulturalnih tradicija, dok je fenomen liminalno-heterogene poetike starije bošnjačke i bosanskohercegovačke literarne tradicije tek jedna od potvrda plodnog susreta različitih kulturnih tradicija na prostoru Bosne u različitim povijesnim razdobljima. Pojam „liminalnosti“ u književnosti ne treba shvaćati samo kao ograničenje, nego i kao bogatstvo bošnjačke i bosanskohercegovačke književnosti u najširem smislu te riječi.

\section{LITERATURA}

[Cevdet Paşa 1991] - Cevdet Paşa. Tezākir, yayınlayan C. Baysun, Türk Tarih Kurumu, Basımevi, Ankara.

[Begić 1987] - M. Begić, Naš muslimanski pisac i njegova raskršća, [u:] Midhat Begić. Raskršća IV: Bosanskohercegovačke književne teme, Djela 5, priredila H. Kapidžić Osmanagić, Veselin Masleša, Svjetlost, Sarajevo.

[Duraković 1998] - E. Duraković, Modeli izučavanja bošnjačke književnosti, [u:] Bošnjačka književnost u književnoj kritici, knj. 1: Starija književnost, ed. E. Duraković, F. Nametak, Alef, Sarajevo.

[Džanko 2001] - M. Džanko, Povijesna opterećenja, smetnje i hipoteke u proučavanju bošnjačke književnosti u srpsko-hrvatskoj literarnoj histo-riografiji tijekom prve polovice XX. stoljeća, [u:] Razlika/Differance - časopis za kritiku i umjetnost teorije, br. 2, Filozofski fakultet, Tuzla, www.razlika-differance.com/Razlika2/RD2MuhidinDzanko.pdf (30.03.2016).

[Kodrić 2012] - S. Kodrić, Književnost sjećanja: Kulturalno pamćenje i reprezentacija prošlosti u novijoj bošnjačkoj književnosti, Slavistički komitet, Sarajevo.

[Kodrić 2013] - S. Kodrić, Kulturalno-poetički sinkretizmi i liminalno-hibridni oblici kao kulturalno-memorijski i interliterarni fenomen novije bošnjačke/bosanskohercegovačke književnosti: na primjeru ranog pjesničkog djela Safvet-bega Bašagića, [u:] Njegoševi dani IV - Zbornik radova, Univerzitet Crne Gore - Filozofski fakultet, Nikšić.

[Rizvić 1994] - M. Rizvić, Panorama bošnjačke književnosti, NIP Ljiljan, Sarajevo.

[Riker 1993] - P. Riker, Vreme i priča, prev. S. Miletić, A. Moralić, Sremski Karlovci-Novi Sad. 
Adnan Kadrić

\title{
THE LIMINAL-HETEROGENEOUS POETICS OF THE ELDER BOSNIAKS' LITERATURE IN THE CONTEXT OF WESTERN BALKAN CULTURAL POLYPHONY
}

\author{
(Summary)
}

The article deals with the issue of liminality in literary-historical and cultural studies. The intention is to point out the phenomenon of intercultural and heterogeneous poetics of elder Bosniaks' literature. From the anthropological point of view, it is very significant to draw attention to the phenomenon of the historical cyclic-liminal literary identity of elder Bosniaks' literature. It is, above all, about the various cultural and literary text poetics that have to merge into a unique identitarian mixture containing apparently equally disparate cultural-civilization guidelines. In this way, it could be relativized. The discontinuity of literary identity, and the phenomenon of older literary tradition again reaffirm themselves through the return to a beforehand completed cycle in the history of literature in general. 